CORRECTION

\title{
Correction: Effective drug treatment identified by in vivo screening in a transplantable patient-derived xenograft model of chronic myelomonocytic leukemia
}

Arnold Kloos, Konstantinos Mintzas, Lina Winckler, Razif Gabdoulline, Yasmine Alwie, Nidhi Jyotsana (D), Nadine Kattre, Renate Schottmann, Michaela Scherr, Charu Gupta, Felix F. Adams (iD, Adrian Schwarzer, Dirk Heckl, Axel Schambach, Suzan Imren, R. Keith Humphries, Arnold Ganser, Felicitas Thol and Michael Heuser (D)

(c) The Author(s) 2021

Leukemia (2021) 35:3629; https://doi.org/10.1038/s41375-021-01459-z

Correction to: Leukemia https://doi.org/10.1038/s41375-020-0929-3, published online 24 June 2020

The article Effective drug treatment identified by in vivo screening in a transplantable patient-derived xenograft model of chronic myelomonocytic leukemia, written by Arnold Kloos, Konstantinos Mintzas, Lina Winckler, Razif Gabdoulline, Yasmine Alwie, Nidhi Jyotsana, Nadine Kattre, Renate Schottmann, Michaela Scherr, Charu Gupta, Felix F. Adams, Adrian Schwarzer, Dirk Heckl, Axel Schambach, Suzan Imren, R. Keith Humphries, Arnold Ganser, Felicitas Thol, Michael Heuser, was originally published Online First without Open Access. After publication in volume 34, issue 11, page 2951-2963 the author decided to opt for Open Choice and to make the article an Open Access publication. Therefore, the copyright of the article has been changed to (c) The Author(s) 2020 and the article is forthwith distributed under the terms of the Creative Commons Attribution.

\begin{abstract}
cc) (i) Open Access This article is licensed under a Creative Commons adaptation, distribution and reproduction in any medium or format, as long as you give appropriate credit to the original author(s) and the source, provide a link to the Creative Commons license, and indicate if changes were made. The images or other third party material in this article are included in the article's Creative Commons license, unless indicated otherwise in a credit line to the material. If material is not included in the article's Creative Commons license and your intended use is not permitted by statutory regulation or exceeds the permitted use, you will need to obtain permission directly from the copyright holder. To view a copy of this license, visit http://creativecommons. org/licenses/by/4.0/.
\end{abstract}

C The Author(s) 2021 